\title{
Synthesis and biological evaluation of $\left[{ }^{18} \mathrm{~F}\right]$ tetrafluoroborate: a PET imaging agent for thyroid disease and reporter gene imaging of the sodium/iodide symporter
}

\author{
Maite Jauregui-Osoro • Kavitha Sunassee - Amanda J. Weeks • David J. Berry • \\ Rowena L. Paul • Marcel Cleij • Jasvinder Paul Banga • Michael J. O'Doherty • \\ Paul K. Marsden • Susan E. M. Clarke • James R. Ballinger • Istvan Szanda • \\ Sheue-Yann Cheng • Philip J. Blower
}

Received: 4 February 2010 /Accepted: 3 June 2010 / Published online: 25 June 2010

(C) The Author(s) 2010. This article is published with open access at Springerlink.com

\begin{abstract}
Purpose The human sodium/iodide symporter (hNIS) is a well-established target in thyroid disease and reporter gene imaging using gamma emitters ${ }^{123} \mathrm{I}$-iodide, ${ }^{131}$ I-iodide and ${ }^{99 \mathrm{~m}}$ Tc-pertechnetate. However, no PET imaging agent is routinely available. The aim of this study was to prepare and evaluate ${ }^{18} \mathrm{~F}$-labelled tetrafluoroborate $\left(\left[{ }^{18} \mathrm{~F}\right] \mathrm{TFB}\right)$ for PET imaging of hNIS.
\end{abstract}

Electronic supplementary material The online version of this article (doi:10.1007/s00259-010-1523-0) contains supplementary material, which is available to authorized users.

M. Jauregui-Osoro $\cdot$ K. Sunassee $\cdot$ A. J. Weeks $\cdot$ D. J. Berry $\cdot$

R. L. Paul $\cdot$ M. Cleij · M. J. O’Doherty $\cdot$ P. K. Marsden •

I. Szanda $\cdot$ P. J. Blower $(\bowtie)$

Division of Imaging Sciences, King's College London,

4th Floor Lambeth Wing, St Thomas' Hospital,

London SE1 7EH, UK

e-mail: Philip.Blower@kcl.ac.uk

M. Jauregui-Osoro

e-mail: Maite.Jauregui-Osoro@kcl.ac.uk

J. P. Banga

Division of Cell and Gene Based Therapy,

King's College London,

London, UK

S. E. M. Clarke $\cdot$ J. R. Ballinger

Department of Nuclear Medicine,

Guy's and St Thomas' NHS Trust,

London, UK

S.-Y. Cheng

Laboratory of Molecular Biology, National Cancer Institute,

Bethesda, USA
Methods $\left[{ }^{18} \mathrm{~F}\right] \mathrm{TFB}$ was prepared by isotopic exchange of $\mathrm{BF}_{4}{ }^{-}$with $\left[{ }^{18} \mathrm{~F}\right]$ fluoride in hot hydrochloric acid and purified using an alumina column. Its identity, purity and stability in serum were determined by HPLC, thin-layer chromatography (TLC) and mass spectrometry. Its interaction with NIS was assessed in vitro using FRTL-5 rat thyroid cells, with and without stimulation by thyroidstimulating hormone (TSH), in the presence and absence of perchlorate. Biodistribution and PET imaging studies were performed using $\mathrm{BALB} / \mathrm{c}$ mice, with and without perchlorate inhibition.

Results $\left[{ }^{18} \mathrm{~F}\right] \mathrm{TFB}$ was readily prepared with specific activity of $10 \mathrm{GBq} / \mathrm{mg}$. It showed rapid accumulation in FRTL-5 cells that was stimulated by TSH and inhibited by perchlorate, and rapid specific accumulation in vivo in thyroid (SUV=72 after $1 \mathrm{~h}$ ) and stomach that was inhibited $95 \%$ by perchlorate.

Conclusion $\left[{ }^{18} \mathrm{~F}\right] \mathrm{TFB}$ is an easily prepared PET imaging agent for rodent NIS and should be evaluated for hNIS PET imaging in humans.

Keywords ${ }^{18} \mathrm{~F}$. PET . Tetrafluoroborate .

Sodium/iodide symporter Thyroid

\section{Introduction}

Historically, molecular imaging of the human sodium/ iodide symporter (hNIS) [1,2] with radioiodide has made a major contribution to the management of thyroid cancer and the development of nuclear medicine [3, 4]. The success of $\left[{ }^{131} \mathrm{I}\right]$ iodide treatment for thyroid cancer and hyperthyroidism founded the field of therapeutic nuclear 
medicine, and imaging with $\left[{ }^{131} \mathrm{I}\right]$ iodide and $\left[{ }^{123} \mathrm{I}\right]$ iodide has been fundamental to diagnosis of disease and monitoring treatment outcomes for over half a century. More recently, radioiodine imaging has found a role in dose planning in radionuclide therapy $[5,6]$. In addition, recently hNIS has taken on a new research role as a reporter gene [7-9] in gene therapy and imaging of cell migration and differentiation. Reporter gene imaging with radioiodide SPECT is feasible because hNIS is normally expressed in only a few tissues (thyroid, gastric mucosa, salivary glands, kidneys and lactating breast) $[10] .\left[{ }^{99 \mathrm{~m}} \mathrm{Tc}\right]$ pertechnetate offers a more readily available and cheaper substitute for SPECT imaging where reduced radiation absorbed dose is important.

Despite the historical importance of hNIS imaging, current methods have limitations. SPECT has limited resolution and sensitivity for detecting low volume disease, especially if normal functioning thyroid remnants remain. With ${ }^{131} \mathrm{I}$, and to a lesser extent with ${ }^{123} \mathrm{I}$, "stunning" occurs-low activities administered for imaging may reduce the effectiveness of the therapy dose of ${ }^{131} \mathrm{I}$ [4]. The half-lives of both iodine radionuclides are longer than required for imaging, so absorbed radiation doses are unnecessarily high. Resolution and sensitivity of PET are significantly better than those of SPECT, resulting in better delineation of small regions of tracer uptake or lack of uptake. Better quantification of the absolute amount of tracer in small regions is also possible with PET. A PET alternative to SPECT as the primary hNIS imaging procedure could thus improve sensitivity of detection of metastases and cold nodules, tumour volume measurement and hNIS reporter gene imaging.

Current options for PET imaging of hNIS expression are very limited. The positron emitter $\left[{ }^{124} \mathrm{I}\right]$ iodide $[5,6$, 8, 11-16] has shown better sensitivity for detection of metastases than SPECT [13]. Volume determination, and hence accurate dosimetry, was feasible for lesions as small as $13 \mathrm{~mm}$ diameter $[5,16] .{ }^{124} \mathrm{I}$, however, suffers from several disadvantages that prevent routine diagnostic use. The low positron yield (23\%) and long half-life mean that the radiation dose per unit positron yield from ${ }^{124} \mathrm{I}$ is approximately 18 times that from ${ }^{18} \mathrm{~F}$. This is compounded by high positron energy $\left(\mathrm{E}_{\max }=2.14 \mathrm{MeV}\right)$ and high energy gamma emission, both of which degrade image quality. Moreover, its availability is severely limited and its production relatively complex. $\left[{ }^{94 \mathrm{~m}} \mathrm{Tc}\right.$ ] pertechnetate [17] could be considered, but is not a plausible replacement because it is not widely available and its production is complex. The ideal radionuclide would be ${ }^{18} \mathrm{~F}$, as it is readily available, and has a half-life (110 min) compatible with typical imaging times and a low energy $\left(E_{\max }=0.634 \mathrm{MeV}\right)$, high yield $(97 \%)$ positron emission.
Many non-natural substrates for NIS are known, some of which are important medically as iodide uptake inhibitors (e.g. perchlorate) $\left.[2,18-21] .{ }^{99 \mathrm{~m}} \mathrm{Tc}\right]$ pertechnetate is used for thyroid SPECT, and $\left[{ }^{188}\right.$ Re]perrhenate $[22,23]$ and $\left[{ }^{211} \mathrm{At}\right]$ astatide $[24,25]$ have been proposed for radionuclide therapy [22-24, 26, 27]. The key shared physicochemical features are uninegative charge, similar ionic radius/volume and similar space-filling properties, i.e. roughly spherical (e.g. tetrahedral, non-dipolar) [2, 19]. Smaller anions such as fluoride, chloride and bromide do not compete as substrates [2]. Tetrafluoroborate (TFB) [19] is a fluorine-containing ion that interacts with NIS. It has not been used for PET imaging, but in the 1950s and early 1960 s, before both the advent of clinical PET and the identification and characterisation of hNIS [2], Anbar et al. produced data suggesting to us that labelled TFB would have good potential for thyroid imaging $[18,19,28]$ : TFB inhibits iodide uptake in thyroid $[19,29]$ in vivo and is specifically accumulated in thyroid [18], reaching a high thyroid to blood concentration ratio (at least 60:1 even at low specific activities) [19]. It is hydrolytically stable under physiological conditions [28] and is not significantly metabolised [19]. TFB has low toxicity (rat $\mathrm{LD}_{50}$ : $550 \mathrm{mg} / \mathrm{kg}$ when administered subcutaneously, according to data from $\mathrm{NaBF}_{4}$ material safety data sheet). It is a constituent of ${ }^{99 \mathrm{~m}} \mathrm{Tc}$-sestamibi kits for myocardial imaging $(78 \mu \mathrm{g} / \mathrm{kit})$ and presents no hazard when intravenously administered. It has been radiolabelled with ${ }^{18} \mathrm{~F}$ by isotopic exchange under acidic conditions, although published methods are not suitable for producing a radiotracer for clinical PET [28]. Despite this potential, $\left[{ }^{18} \mathrm{~F}\right] \mathrm{TFB}$ has not been used for investigation of thyroid pathologies, or indeed for PET imaging in any context. Today's nuclear medicine environment is better equipped, both to produce this tracer and to exploit its potential imaging applications. The relatively recent characterisation of cloned NIS [1,20], and its use in gene therapy, have created new applications for NIS tracers. A simple and effective preparation of $\left[{ }^{18} \mathrm{~F}\right]$ TFB could permit quantitative, high-resolution imaging of NIS expression in this context without undue patient radiation burden.

\section{Materials and methods}

\section{Radiochemistry}

Initial investigations of isotopic exchange labelling of sodium tetrafluoroborate (Sigma-Aldrich, Gillingham, UK, 99\%) were performed at various concentrations and temperatures with $\left[{ }^{18} \mathrm{~F}\right]$ fluoride, obtained directly from protonirradiated $\left[{ }^{18} \mathrm{O}\right]$ water $(97$ atom\%, Isochem Ltd., Hook, UK; $11 \mathrm{MeV}$ protons from a CTI RDS 112 cyclotron, beam 
current $30 \mu \mathrm{A}$, irradiation time 10-20 min) without use of ion exchange, Kryptofix or azeotropic distillation. The $\mathrm{pH}$ was modified using hydrochloric acid (Fisher Scientific, Loughborough, UK).

\section{Radioanalytical methods}

Labelling was monitored by thin-layer chromatography (TLC) using alumina TLC strips with fluorescent indicator (length $100 \mathrm{~mm}$, Sigma-Aldrich, Gillingham, UK) with methanol as mobile phase. Strips were scanned using a Mini-scan radio TLC scanner with Flow-Count detector (LabLogic, Sheffield, UK). The presence of TFB at Rf $0.80-0.85$ was demonstrated by scraping the alumina from the TLC plate, extracting it with water and analysing by anion LC-electrospray mass spectrometry (MS) (Agilent 6520 Accurate-Mass Q-TOF LC/MS, Agilent Technologies UK Ltd.). A reverse UV HPLC method was developed [Agilent 1200 series system with a quadruple pump, UV detector $(254 \mathrm{~nm})$ and radioactivity detector (LabLogic, Sheffield, UK)] utilising a SGE Exsil ODS (reverse phase) column, $5 \mu \mathrm{m}, 250 \times 4.0 \mathrm{~mm}$ (SGE Europe Ltd., Bucks, UK) with a mobile phase of $1 \mathrm{mM}$ tetrabutylammonium hydroxide and $1.3 \mathrm{mM}$ potassium hydrogen phthalate in water ( $\mathrm{pH} 7.5$ ) flowing at $1.0 \mathrm{ml} / \mathrm{min}$, sample volume $20 \mu \mathrm{l}$. The method was validated by its ability to separate a range of uninegative ions of similar size and lipophilicity (in order of elution: fluoride, chloride, bromide, nitrate, sulphate, iodide and tetrafluoroborate). The system was calibrated to measure TFB concentration using standard aqueous sodium tetrafluoroborate solutions. The elution time of TFB and the identity of the eluted anion were further confirmed by LC-MS analysis of fractions as above.

Synthesis of $\left[{ }^{18} \mathrm{~F}\right] \mathrm{TFB}$

From the above experiments the following automated (but not fully optimised) labelling protocol was developed using an Eckert and Ziegler Modular-Lab module (Imaging Equipment Ltd., Bristol, UK). $\left[{ }^{18} \mathrm{~F}\right]$ fluoride (12-18 GBq) was trapped by passage of the irradiated water $(4 \mathrm{ml})$ through a QMA (Waters UK, Elstree, UK) cartridge conditioned with $1.0 \mathrm{M}$ sodium hydrogen carbonate. Hydrochloric acid $(1.5 \mathrm{M}, 1.2 \mathrm{ml})$, prepared by dilution of $5 \mathrm{M}$ hydrochloric acid with water for injections (BP, Hameln Pharmaceuticals, Gloucester, UK), was then passed through, eluting the $\left[{ }^{18} \mathrm{~F}\right]$ fluoride into the reactor which contained sodium tetrafluoroborate $(1 \mathrm{mg}$ in $0.1 \mathrm{ml} 1.5 \mathrm{M}$ $\mathrm{HCl})$. The reaction mixture $(1.3 \mathrm{ml})$ was heated to $120^{\circ} \mathrm{C}$ for $10 \mathrm{~min}$, cooled to $25^{\circ} \mathrm{C}$ and passed through a silver ionloaded cation exchange cartridge (OnGuard II AG, Dionex, Leeds, UK, conditioned with $10 \mathrm{ml}$ water) to remove chloride and raise the $\mathrm{pH}$, and through two alumina columns (Waters SepPak Light Alumina N, conditioned with $10 \mathrm{ml}$ water and $5 \mathrm{ml}$ air, to remove unreacted $\left[{ }^{18} \mathrm{~F}\right]$ fluoride) and a sterile Millex-GS $0.22 \mu \mathrm{m}$ filter unit (Millipore UK, Watford, UK), and washed through with a further $2 \mathrm{ml}$ water for injections, into a nitrogen-filled sterile vial. The process, including irradiation, synthesis and purification, takes less than $1 \mathrm{~h}$. Analysis and quality control were performed as described above before the product was used in biological studies.

\section{Stability/shelf life}

The product was subjected to HPLC and TLC analysis as described above after standing at room temperature for $5 \mathrm{~h}$.

\section{Serum stability}

A total of $100 \mu \mathrm{l}$ of the product was added to $1 \mathrm{ml}$ human serum (male, type AB, Sigma-Aldrich, Gillingham, UK) and the mixture was incubated at $37^{\circ} \mathrm{C}$. Aliquots $(100 \mu \mathrm{l})$ were withdrawn hourly up to $4 \mathrm{~h}$ into microcentrifuge tubes and mixed with an equal volume of ethanol to precipitate serum proteins. After centrifugation the supernatant was analysed by HPLC and TLC as described above.

\section{Cell culture}

Media and reagents were obtained from PAA Laboratories (Yeovil, UK) and hormones from Sigma-Aldrich (Poole, UK). The Fisher rat thyroid cell line FRTL-5 was kindly donated by Prof. Jan Smit and Dr. Guido Hovens (Leiden University, The Netherlands) and grown in a humidified incubator at $37^{\circ} \mathrm{C}$ with $5 \% \mathrm{CO}_{2}$ in Hams:F12 medium supplemented with $10 \%$ fetal bovine serum, penicillin/ streptomycin, minimal essential medium amino acids and a hormone mixture containing insulin $(10 \mu \mathrm{g} / \mathrm{ml})$, hydrocortisone $(3.6 \mathrm{ng} / \mathrm{ml})$, glycyl-histidyl-lysine acetate $(10 \mathrm{ng} / \mathrm{ml})$, transferrin $(5 \mu \mathrm{g} / \mathrm{ml})$, somatostatin $(10 \mathrm{ng} / \mathrm{ml})$ and bovine thyroid-stimulating hormone (TSH) $(1 \mathrm{mU} / \mathrm{ml})$. For experiments without TSH stimulation, cells were maintained in the same medium with all hormones except TSH for 7 days prior to the experiment.

Tracer accumulation in FRTL-5 cells

Cells were seeded $(150,000$ per well, $n=3$ for each treatment in each of two independent experiments) into 24-well plates (one plate for each time point, three wells for each treatment) and incubated for 18-24 h. Prior to the assay, cells were washed twice in $1 \mathrm{ml}$ phosphate-buffered saline (PBS), and Hanks' balanced salt solution (HBSS, $500 \mu \mathrm{l})$ was added to each well with or without $10 \mu \mathrm{M}$ sodium perchlorate. The plate was incubated for $10 \mathrm{~min}$ 
prior to the addition of $0.1 \mathrm{MBq}\left[{ }^{18} \mathrm{~F}\right] \mathrm{TFB}$ (specific activity $10 \mathrm{GBq} / \mathrm{mg}$ ) in a volume of $10 \mu \mathrm{l}$ per well. At intervals from 1 to $120 \mathrm{~min}$ the radioactive medium was aspirated and cells were washed twice with $1 \mathrm{ml}$ HBSS. Cell-bound radioactivity was extracted by addition of $500 \mu \mathrm{l} 1 \mathrm{M}$ $\mathrm{NaOH}$ for $10 \mathrm{~min}$. Cell-associated activity was counted in a gamma counter (Wallac 1282-001 Compugamma CS). Accumulation was expressed as counts per minute (cpm) per $\mu \mathrm{g}$ cellular protein, which was measured using a Novagen bicinchoninic acid protein assay kit (Merck Chemicals Ltd., Nottingham, UK).

Tracer efflux from FRTL-5 cells

Cells were seeded (150,000 per well) and incubated in 24well plates with triplicate wells for each time point as described above. After addition of $0.1 \mathrm{MBq}\left[{ }^{18} \mathrm{~F}\right] \mathrm{TFB}$ to each well and incubation for $1 \mathrm{~h}$, the radioactive medium was removed and cells were washed twice in $1 \mathrm{ml}$ HBSS and $1 \mathrm{ml} \mathrm{HBSS}$ was added to each well. At intervals from 5 to $120 \mathrm{~min}$ the medium was collected and the activity remaining in the cells was extracted with $1 \mathrm{M} \mathrm{NaOH}$ $(500 \mu \mathrm{l})$ for $10 \mathrm{~min}$. Radioactivity was counted in HBSS using a gamma counter. Radionuclide efflux was expressed as the percentage of the total activity in cells immediately after washing in HBSS.

\section{Biodistribution}

Animal studies were carried out in accordance with UK Research Councils' and Medical Research Charities' guidelines on Responsibility in the Use of Animals in Bioscience Research, under a UK Home Office licence. Female BALB/ c mice ( $n=3$ per group, aged 9-12 weeks, $22.4 \pm 1.76 \mathrm{~g}$ ) were purchased from Harlan Laboratories, UK. One group received i.p. injections of $50 \mu \mathrm{l}$ PBS and another received $50 \mu$ sodium perchlorate (Sigma-Aldrich, Gillingham, UK, $100 \mathrm{mg} / \mathrm{ml}$ ) in PBS. After $30 \mathrm{~min}$, both groups received i.v. (tail vein) injections of approximately $3 \mathrm{MBq}(50 \mu \mathrm{l})\left[{ }^{18} \mathrm{~F}\right]$ TFB (specific activity $10 \mathrm{GBq} / \mathrm{mg}$ ). Animals were killed at 60 min post-injection (p.i.) and tissues explanted, blotted dry, weighed (except thyroid, vide infra) and counted on a gamma counter (the carcass activity was measured with an ionisation chamber cross-calibrated with the gamma counter). Because of the small size and intimate attachment to trachea, normal thyroid glands were explanted along with a small piece of trachea and a standard thyroid tissue mass of $3.6 \mathrm{mg}$ [30] used in all SUV calculations. A separate piece of thyroid-free trachea was taken and weighed to confirm that activity in trachea tissue did not significantly affect the thyroid SUV calculation. A third group $(n=4$, range: $20.6 \pm$ $1.53 \mathrm{~g}$ ), treated as above without sodium perchlorate, were killed at 30 min p.i. Uptake in each tissue was expressed as
SUV, calculated as activity (cpm) per gram of tissue divided by total recovered activity ( $\mathrm{cpm}$ ) per gram of whole body mass. Excreted radioactivity, radioactivity in the tail and mass of the tail were excluded from the total recovered activity.

Imaging

A BALB/c mouse (age and weight as above) and a $T R \beta^{P V / P V}$ transgenic mouse [31] derived from a colony bred at King's College London (male, 11 months old, $27.8 \mathrm{~g}$ ) received i.v. (tail vein) injections of $5 \mathrm{MBq}$ of $\left[{ }^{18} \mathrm{~F}\right] \mathrm{TFB}(50 \mu \mathrm{l})$. With the mice under isofluorane anaesthesia in a Minerve imaging chamber, PET/CT scans were acquired $30 \mathrm{~min}$ p.i. using a NanoPET/CT scanner (Bioscan, Paris, France) with PET acquisition time 2,400 $\mathrm{s}$, coincidence relation: 1-3; image reconstruction: ordered subset expectation maximization (OSEM) with single-slice rebinning (SSRB) 2-D line of response (LOR), energy window: 400-600 keV, filter: RamLak cut-off 1 , number of iterations/subsets: 8/6. The biodistribution of the tracer in the $T R \beta^{P V / P V}$ mouse was then determined ex vivo by dissection and organ counting after sacrificing at $3.5 \mathrm{~h}$ p.i.

\section{Results}

Synthesis, purification and characterisation of $\left[{ }^{18} \mathrm{~F}\right] \mathrm{TFB}$

Initial experiments on exchange labelling of sodium tetrafluoroborate with $\left[{ }^{18} \mathrm{~F}\right]$ fluoride showed that the reaction rate and efficiency increased with increasing concentration of TFB (Online Resource 1), increasing temperature and increasing acid concentration, reaching a labelling efficiency of $45 \%$ after $10 \mathrm{~min}$ at $75^{\circ} \mathrm{C}$ with a $\mathrm{NaBF}_{4}$ concentration of $10 \mathrm{mg} / \mathrm{ml}$ and $\mathrm{HCl}$ concentration of $1 \mathrm{M}$. These initial experiments also yielded a TLC method able to quantitatively distinguish $\left[{ }^{18} \mathrm{~F}\right] \mathrm{TFB}(\mathrm{Rf} 0.80-0.85)$ from $\left[{ }^{18} \mathrm{~F}\right]$ fluoride (Rf 0) (Fig. 1). It was difficult to prove that the radioactive spot at $\mathrm{Rf} 0.80-0.85$ represents $\left[{ }^{18} \mathrm{~F}\right] \mathrm{TFB}$ using TLC alone since cold TFB has no chromophore. However, electrospray MS confirmed the presence of TFB in the Rf $0.80-0.85$ fraction $\left\{87\right.$ and $86,100 \%\left(\mathrm{M}^{-}\right)$; and $\left.197,25 \%\left(\left[\mathrm{Na}\left(\mathrm{BF}_{4}\right)_{2}\right]^{-}\right)\right\}$. To support the identification of labelled TFB, an HPLC method was developed and validated by demonstrating reproducible separation of a range of inorganic monoanions. In this method, $\left[{ }^{18} \mathrm{~F}\right] \mathrm{TFB}$ eluted between 6 and $7 \mathrm{~min}$ while $\left[{ }^{18} \mathrm{~F}\right]$ fluoride eluted at 3 min (Fig. 2). These times agreed with those determined by spiking the radiotracer with the cold standards. $\left[{ }^{18} \mathrm{~F}\right]$ fluoride was easily removed by passage through two disposable alumina cartridges, eluting with water or saline, as demonstrated using the TLC (Fig. 1) and HPLC (Fig. 2) 
TFB

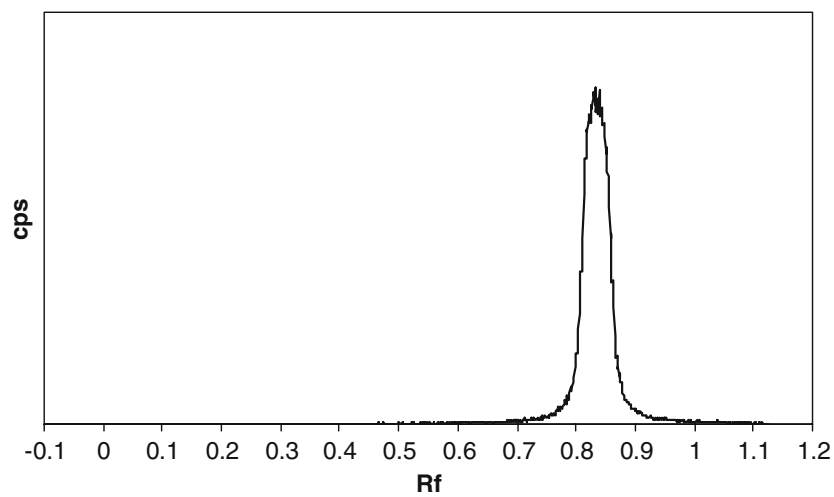

FLUORIDE

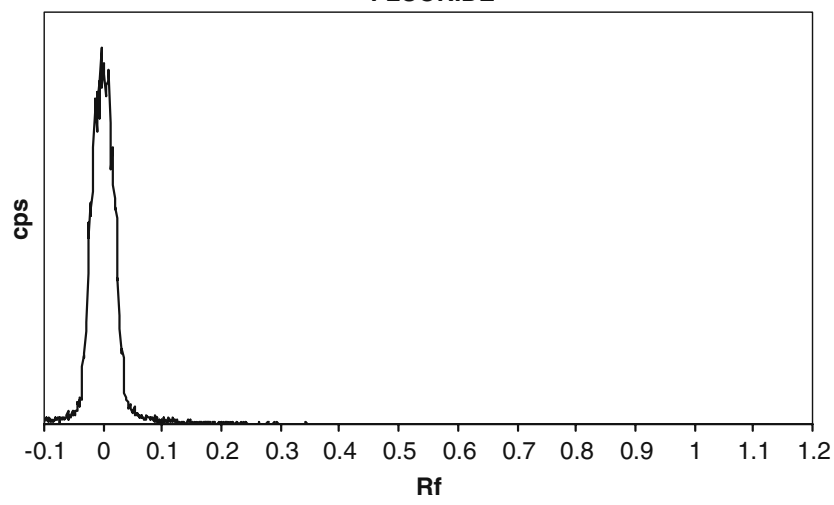

Fig. 1 TLC of purified $\left[{ }^{18} \mathrm{~F}\right] \mathrm{TFB}$ (upper) and $\left[{ }^{18} \mathrm{~F}\right]$ fluoride (lower) using alumina stationary phase and methanol mobile phase, showing their clear separation and the purity of the final product
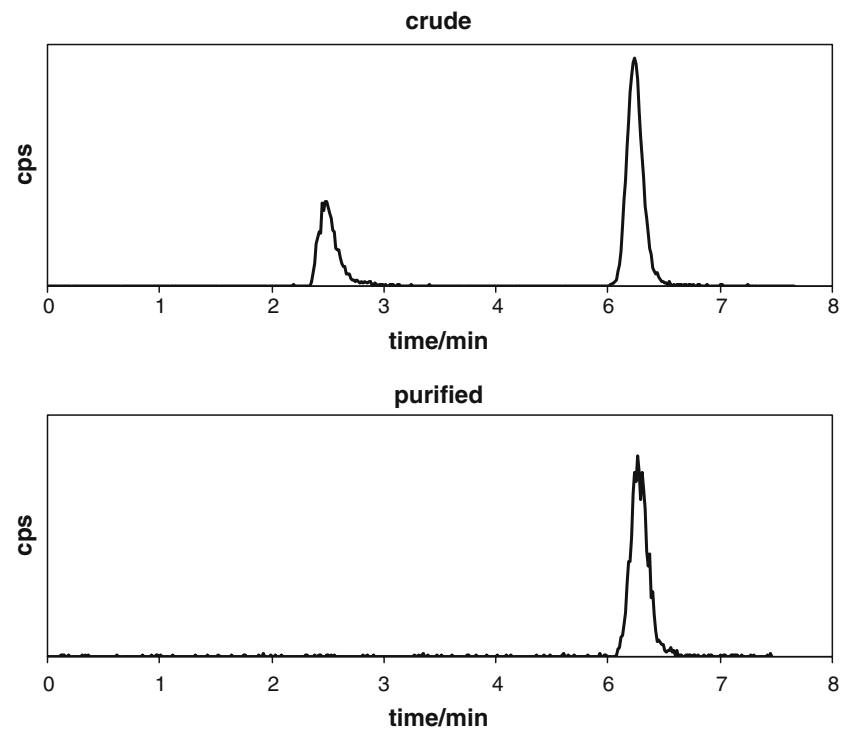

Fig. 2 Radio-HPLC of product of exchange ${ }^{18} \mathrm{~F}$ labelling of tetrafluoroborate, before (upper) and after (lower) purification using alumina column. For HPLC conditions see "Materials and methods" section methods described above. To produce samples suitable for biological evaluation, it was necessary to reduce the acidity and chloride concentration without substantial dilution, for which filtration through a Dionex AG (a cation exchanger loaded with silver ions) cartridge proved efficacious, raising the $\mathrm{pH}$ to between 6 and 7 without trapping $\left[{ }^{18} \mathrm{~F}\right] \mathrm{TFB}$.

Further development was conducted with use of an automated synthesis apparatus. Labelling efficiency was increased further by increasing the reaction temperature $\left(120^{\circ} \mathrm{C}\right)$ and time $(20 \mathrm{~min})$ and $\mathrm{HCl}$ concentration $(1.5 \mathrm{M})$. The specific activity of the product varied depending on the starting activity of ${ }^{18} \mathrm{~F}$. By starting with $12-18 \mathrm{GBq}{ }^{18} \mathrm{~F}$ and $1 \mathrm{mg}$ sodium tetrafluoroborate, a specific activity of $10 \mathrm{GBq} / \mathrm{mg}(1 \mathrm{GBq} / \mu \mathrm{mol})$ was routinely achieved, with an isolated radiochemical yield of approximately $10 \%$ uncorrected for decay in a volume of $2 \mathrm{ml}$. Radiochemical purity consistently exceeded $96 \%$. The $\mathrm{pH}$ was between 6 and 7. The production was complete within $30 \mathrm{~min}$ from end of bombardment (EOB).

Shelf life and stability in serum

The speciation of radioactivity in the $\left[{ }^{18} \mathrm{~F}\right] \mathrm{TFB}$ preparation, as determined by TLC and HPLC, was unchanged after standing at room temperature for $5 \mathrm{~h}$. Similarly, incubation in human serum at $37^{\circ} \mathrm{C}$ for $4 \mathrm{~h}$ gave no change in the TLC or HPLC patterns.

In vitro accumulation in rat thyroid cells

$\left[{ }^{18} \mathrm{~F}\right] \mathrm{TFB}$ showed rapid accumulation in NIS-expressing FRTL-5 cells, reaching a plateau between 5 and $20 \mathrm{~min}$. The plateau count rate shown in Fig. 3 corresponds to an intracellular to extracellular concentration ratio of approximately 22:1. High accumulation was dependent on pretreatment with TSH [32]. If TSH was excluded from the medium for several days prior to the experiment, accumulation was reduced by $>90 \%$ under otherwise identical conditions (Fig. 4). Accumulation by both TSHstimulated and untreated cells was dramatically inhibited (approximately $90 \%$ ) by sodium perchlorate $(10 \mu \mathrm{M})$, a well-established specific inhibitor of iodide uptake by hNIS [33, 34] (Fig. 4). After pre-incubating cells in medium containing $\left[{ }^{18} \mathrm{~F}\right] \mathrm{TFB}$, replacement of the medium with fresh medium containing no $\left[{ }^{18} \mathrm{~F}\right] \mathrm{TFB}$ led to rapid efflux of tracer (more than $90 \%$ within $20 \mathrm{~min}$ ).

In vivo biodistribution and imaging

The biodistribution of $\left[{ }^{18} \mathrm{~F}\right] \mathrm{TFB}$ (Fig. 5) at $60 \mathrm{~min}$ p.i. shows marked uptake in thyroid (mean SUV=71.9). Stomach, which also is well known to express NIS [10], also showed significant uptake $(\mathrm{SUV}=4.4)$ compared to 
TFB uptake in FRTL5 cells
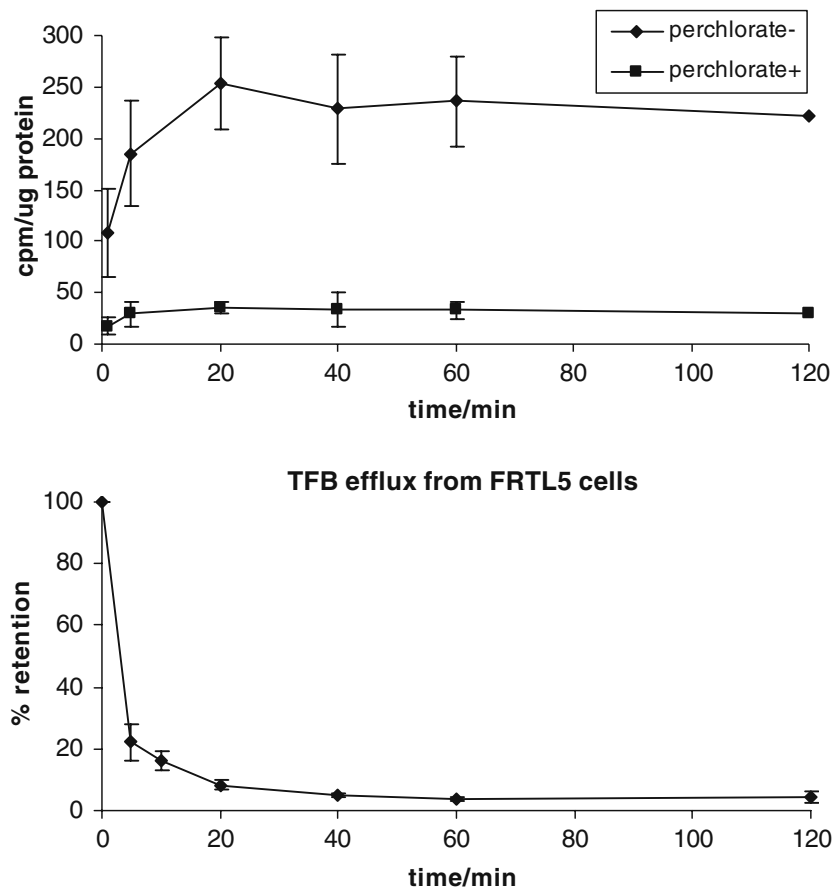

Fig. 3 Upper panel Accumulation of $\left[{ }^{18} \mathrm{~F}\right] \mathrm{TFB}$ in FRTL-5 rat thyroid cells, with and without blocking with perchlorate. Lower panel Efflux of radioactivity from FRTL-5 cells after treatment with $\left[{ }^{18} \mathrm{~F}\right] \mathrm{TFB}$ without perchlorate blocking, followed by replacement of media with $\left[{ }^{18} \mathrm{~F}\right] \mathrm{TFB}$-free media. Error bars represent $1 \mathrm{SD}$

other tissues. At $30 \mathrm{~min}$ p.i. thyroid uptake was slightly higher (SUV=86; data not shown) than at $60 \mathrm{~min}$. There was no significant uptake in visceral organs or bones and elimination was exclusively renal. To demonstrate that $\left[{ }^{18} \mathrm{~F}\right]$ TFB uptake was mediated through NIS, a group of mice receiving sodium perchlorate $30 \mathrm{~min}$ prior to $\left[{ }^{18} \mathrm{~F}\right] \mathrm{TFB}$ administration showed $>95 \%$ suppression of $\left[{ }^{18} \mathrm{~F}\right] \mathrm{TFB}$ accumulation in thyroid $(\mathrm{SUV}=3.2)$ and stomach $(\mathrm{SUV}=$ $0.6)$ at $60 \mathrm{~min}$. In the tumour-bearing $T R \beta^{P V / P V}$ mouse, with greatly and symmetrically enlarged lobes of the thyroid

\section{TFB uptake in FRTL- 5 cells}

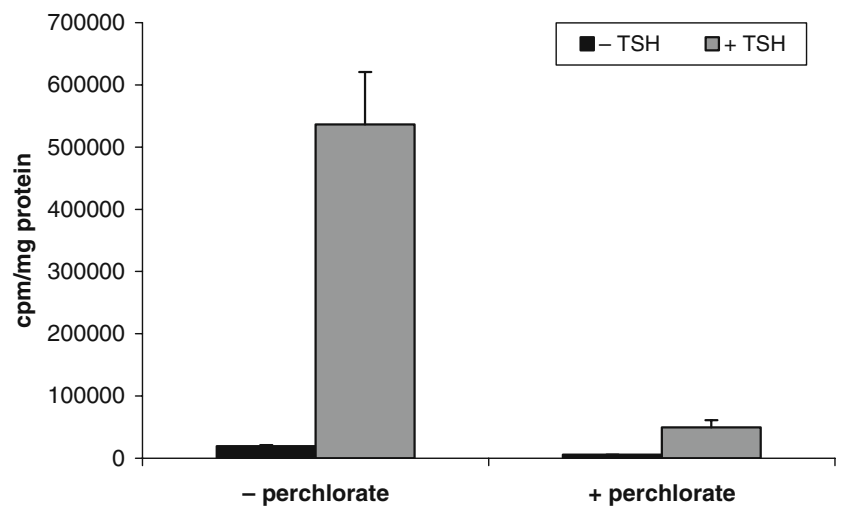

Fig. 4 Effect of perchlorate and TSH on plateau accumulation of $\left[{ }^{18} \mathrm{~F}\right] \mathrm{TFB}$ in FRTL-5 rat thyroid cells $(n=3$, error bars represent $1 \mathrm{SD})$
TFB Biodistribution Balb/C mice $1 \mathrm{~h}$

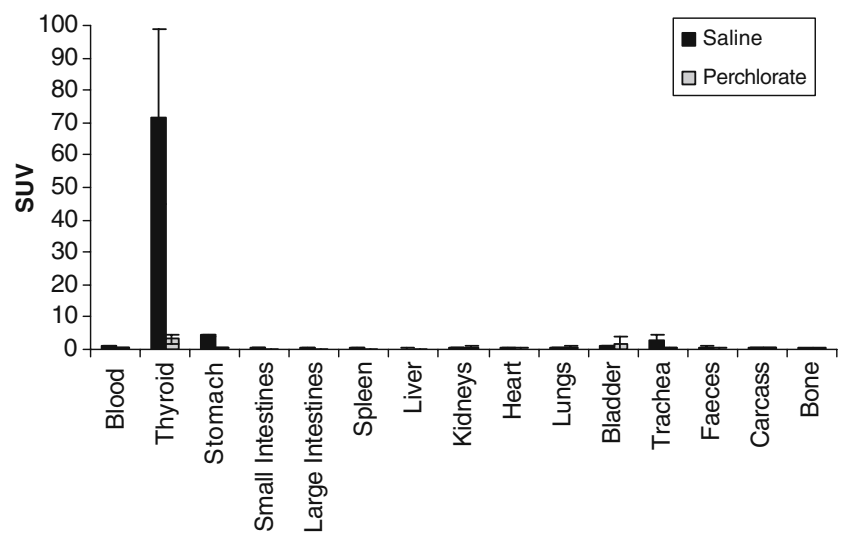

Fig. 5 Biodistribution of $\left[{ }^{18} \mathrm{~F}\right] \mathrm{TFB}$ in normal mice $1 \mathrm{~h}$ p.i.; with and without perchlorate blocking, determined by ex vivo counting of tissues; $n=3$ except bone (femur) where $n=1$. Relative uptake in organs is represented as SUV. Error bars represent $1 \mathrm{SD}$

gland, the thyroid SUV (52 at $3.5 \mathrm{~h}$ p.i.) was reduced compared to normal thyroid tissue but, nevertheless, thyroid was by far the most radioactive organ.

As a preliminary assessment of the potential for PET imaging, a BALB/c mouse was administered i.v. $5 \mathrm{MBq}$ of $\left[{ }^{18} \mathrm{~F}\right]$ TFB and imaged $30 \mathrm{~min}$ later. This gave clear images of thyroid with high target to background ratio and both lobes clearly resolved (Fig. 6). In addition to thyroid and stomach, salivary glands were clearly visualised overlying the thyroid glands. There was also accumulation in lateral parts of the thorax which we attribute to mammary tissue. High radioactivity in the bladder confirmed renal excretion of the tracer. The images also showed that tissues not specifically counted in the biodistribution experiments did not have significant uptake, except salivary glands. A $T R \beta^{P V / P V}$ transgenic mouse with a greatly enlarged spontaneous follicular thyroid tumour was also imaged and despite lower thyroid SUV (52 at $3.5 \mathrm{~h}$ p.i.), the abnormal morphology and increased volume were readily apparent (Fig. 6). Accumulation in salivary glands, stomach, mammary tissue and bladder was less evident in this animal. This is consistent with clinical experience that tissues with low hNIS expression such as thyroid cancer metastases are often less evident when normally functioning thyroid or thyroid remnants are present.

\section{Discussion}

Early production of $\left[{ }^{18} \mathrm{~F}\right] \mathrm{TFB}$ was limited by contemporary methodology for producing ${ }^{18} \mathrm{~F}$, which utilised the ${ }^{16} \mathrm{O}\left({ }^{3} \mathrm{H}\right.$, n) ${ }^{18} \mathrm{~F}$ or ${ }^{18} \mathrm{O}(\mathrm{p}, \mathrm{n}){ }^{18} \mathrm{~F}$ reactions on natural abundance $\mathrm{Li}_{2} \mathrm{CO}_{3}$ or ${ }^{18} \mathrm{O}$-enriched $\mathrm{Li}_{2} \mathrm{CO}_{3}$, using a Van der Graaf generator. An exchange reaction of ${ }^{18} \mathrm{~F}$-fluoride with potassium tetrafluoroborate in acid $(\mathrm{pH} 0)$ at room 
Fig. $6 \mathrm{PET} / \mathrm{CT}$ images. Left and centre Anterior (left) and lateral (centre, to distinguish thyroid from salivary gland uptake) view maximum intensity projections of normal mouse $30 \mathrm{~min}$ after injection of $\left[{ }^{18} \mathrm{~F}\right]$ TFB. Right PET/CT image of $T R \beta^{P V / P V}$ transgenic mouse with thyroid tumour, 30 min after injection with $\left[{ }^{18} \mathrm{~F}\right] \mathrm{TFB}$

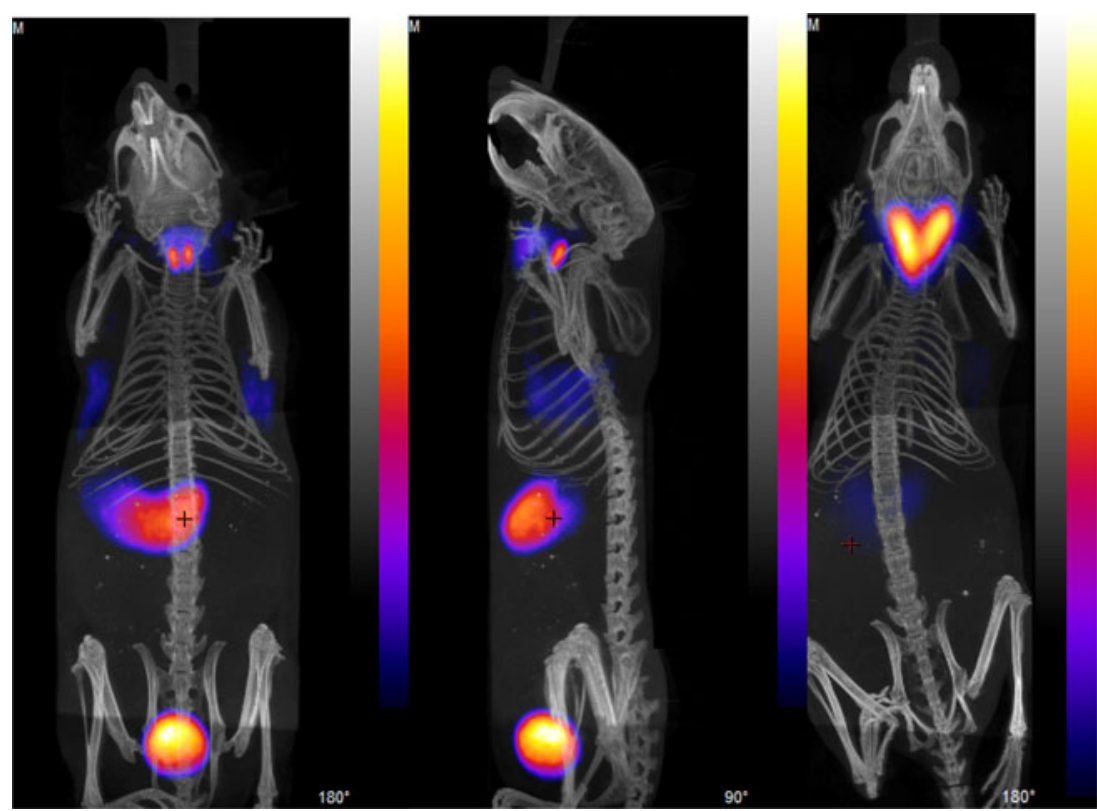

temperature or $100^{\circ} \mathrm{C}$ gave $\left[{ }^{18} \mathrm{~F}\right] \mathrm{KBF}_{4}$, which was purified by recrystallisation $[18,28]$, a method which inherently leads to low specific activity. The route described here is similar in principle, but with modern methods for ${ }^{18} \mathrm{~F}$ production and a new purification method, efficient production is possible to give higher specific activity $\left[{ }^{18} \mathrm{~F}\right]$ TFB adequate for imaging in humans while avoiding saturation of NIS in vivo. This required a compromise between the best \% radiochemical yield and the best specific activity. A satisfactory compromise is described here although some features of the method remain open to significant further optimisation. The neutralisation step involves removal of $\mathrm{HCl}$ by displacing $\mathrm{Ag}^{+}$from a cation exchange resin, with precipitation of $\mathrm{AgCl}$ on the column, a method previously applied to ${ }^{99 \mathrm{~m}} \mathrm{Tc}$ generator eluates [35]. This raises the $\mathrm{pH}$ from 0 to between 6 and 7. The purification method exploits the affinity of fluoride ions for an alumina Sep-Pak cartridge. The method is easily adapted to GMP production. The processing was simple and complete within $30 \mathrm{~min}$ from EOB to readiness for quality control and administration. Quality control was performed using HPLC and TLC. The TLC method described is ideal for routine determination of radiochemical purity of the GMP product. The chromatographic behaviour of the radioactive species identified it as tetrafluoroborate. The final $\mathrm{pH}$, volume and composition are compatible with clinical use. The radiopharmaceutical has a shelf life and serum stability at least commensurate with the physical half-life of ${ }^{18} \mathrm{~F}$, placing no limitations on clinical use.

The rapid uptake and efflux of $\left[{ }^{18} \mathrm{~F}\right] \mathrm{TFB}$ in the rat thyroid cell line parallels the behaviour of $\left[{ }^{99 \mathrm{~m}} \mathrm{Tc}\right]$ pertechnetate (Online Resource 1), which is known to be taken up in cells expressing NIS $[23,36]$. The plateau per cent accumulation represents an intracellular to extracellular concentration ratio of $22: 1$. The rapid efflux on removal of TFB from the supernatant indicates that radioactivity is not irreversibly trapped. It also implies that the washing steps employed before measurement of uptake would have washed out a significant fraction of the cellular radioactivity, and hence the measured plateau intracellular to extracellular $\left[{ }^{18} \mathrm{~F}\right] \mathrm{TFB}$ concentration ratio is likely to significantly underestimate the true ratio. It is clear from the TSH stimulation of uptake, and blocking by perchlorate, that uptake of $\left[{ }^{18} \mathrm{~F}\right] \mathrm{TFB}$ is specific and mediated by NIS. TSH is known to upregulate NIS activity in thyroid cells $[32,37]$, and perchlorate is a known specific inhibitor of NIS [20, 23, 33]. At a specific activity of $10 \mathrm{GBq} / \mathrm{mg}$ the TFB concentration in the wells was about $0.2 \mu \mathrm{M}$. This is within the range of the measured $\mathrm{IC}_{50}$ for inhibition of NISmediated iodide uptake [29], and hence uptake may increase at higher specific activity. Nevertheless, the data provide justification for in vivo biological evaluation of $\left[{ }^{18} \mathrm{~F}\right] \mathrm{TFB}$.

The biodistribution of $\left[{ }^{18} \mathrm{~F}\right] \mathrm{TFB}$ in normal mice and in a $T R \beta^{P V / P V}$ mouse (a transgenic mouse with the "knock-in" PV mutation that spontaneously develops follicular thyroid cancer [31]) was investigated to evaluate its potential use as a tool to image thyroid disease. The SUV in normal thyroid may be subject to systematic error because "standard" weights were used in the calculations; values for standard weights of mouse thyroids ranging from 1.6 to $5 \mathrm{mg}$ have been used by previous authors $[30,38,39]$. The most apparently rigorous measurements were reported by Rugh [30] and we used the value of $3.6 \mathrm{mg}$ accordingly. Nevertheless, we can be confident that the high and specific accumulation of $\left[{ }^{18} \mathrm{~F}\right] \mathrm{TFB}$ in normal thyroid (SUV $>70$ at 
$1 \mathrm{~h}$, higher at $30 \mathrm{~min}$ ), stomach and salivary glands $[10,23$, 40], and rapid renal clearance, parallel the behaviour of $\left[{ }^{99 \mathrm{~m}} \mathrm{Tc}\right]$ pertechnetate. The lack of significant uptake in bone is consistent with the expectation from the observed stability in serum that fluoride ion is not released in vivo. These pharmacokinetic attributes are very similar to those of $\left[{ }^{99 \mathrm{~m}} \mathrm{Tc}\right]$ pertechnetate (Online Resource 1) and are ideal for PET imaging, providing a good match with the half-life of ${ }^{18} \mathrm{~F}$ and offering favourable dosimetry and imaging convenience in humans. The PET/CT images confirm this and show no uptake in bones or joints; hence, there is no in vivo release of $\left[{ }^{18} \mathrm{~F}\right]$ fluoride. Accumulation in thyroid tumour tissue of the $T R \beta^{P V / P V}$ mouse was also marked and indicates the potential value of thyroid tumour imaging with this tracer. The SUV was somewhat reduced compared to that of the normal thyroid tissue; however, this may be because the animal was killed at a later time point $(3.5 \mathrm{~h})$ than the normal mice.

The preliminary PET/CT images shown here represent the first biological imaging data produced with this model of scanner and demonstrate the excellent resolution and sensitivity of the instrument. Full evaluation of the technical capability of the instrument will be published in due course. The two lobes (each $<2 \mathrm{mg}$ ) of the normal mouse thyroid are clearly resolved and the altered morphology of the thyroid tumour is clearly evident. The imaging quality supports the precept that a ${ }^{18} \mathrm{~F}$-labelled tracer for NIS has potential to improve radionuclide imaging of thyroid disease.

The present data are not able to show whether TFB ions are transported into cells by NIS, or whether they merely occupy a binding site. Previously published data show that a transmembrane potential is generated during iodide transport by NIS, consistent with symport of two sodium ions per iodide. The transmembrane potential generated by TFB (and of other competitors such as pertechnetate and perrhenate) is much smaller [2], indicating either that TFB transport occurs with little or no coupling to sodium transport, or that TFB occupies a binding site on NIS but is transported very inefficiently.

Without further optimisation, the present synthesis generates a product with a modest specific activity of

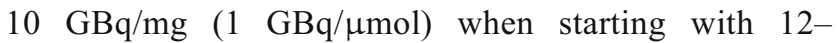
$18 \mathrm{GBq}{ }^{18} \mathrm{~F}$. A likely scenario for production for human use is as follows. Starting with $10 \mathrm{GBq}{ }^{18} \mathrm{~F}$, assuming $50 \%$ incorporation of ${ }^{18} \mathrm{~F}$ into TFB and a production time of $30 \mathrm{~min}$, the specific activity at the time of injection would be in the order of $5 \mathrm{GBq} / \mathrm{mg}$ TFB or $0.5 \mathrm{GBq} / \mu \mathrm{mol}$. An administered activity of $400 \mathrm{MBq}$ would thus contain $0.8 \mu \mathrm{mol}$ TFB. This does not present a significant toxicity hazard (a commercial kit for the preparation of $\left[{ }^{99 \mathrm{~m}} \mathrm{Tc}\right]$ sestamibi contains about this amount). However, upon dilution into the vascular and interstitial compartment the initial concentration in vivo to which NIS is exposed would be in the order of $0.1 \mu \mathrm{M}$. The $\mathrm{IC}_{50}$ of TFB for inhibition of iodide uptake by NIS is between 0.1 and $1 \mu \mathrm{M}$ [29]. Thus, although the images and biodistribution show that the specific activity is clearly adequate for thyroid imaging purposes, optimisation to improve the specific activity perhaps tenfold, preferably without starting with excessive activity of ${ }^{18} \mathrm{~F}$, might well provide a superior target to background ratio.

\section{Conclusion}

We report a simple synthesis of $\left[{ }^{18} \mathrm{~F}\right] \mathrm{TFB}$, with sufficient specific activity for imaging the sodium/iodide symporter in vivo. Preliminary biological assessment shows behaviour very similar to that of ${ }^{99 \mathrm{~m}} \mathrm{Tc}$-pertechnetate and justifies evaluation of $\left[{ }^{18} \mathrm{~F}\right] \mathrm{TFB}$ in humans. It may find applications in pre- and post-surgical evaluation of primary thyroid malignancy and detection of metastases, and for imaging expression of hNIS as a reporter gene, offering the possibility of improved image quality and quantification compared to ${ }^{99 \mathrm{~m}} \mathrm{Tc}$-pertechnetate at the expense of a higher effective radiation dose per injected activity.

Acknowledgements This work was supported by grants from Guy's \& St Thomas' Charity, Cancer Research UK, and EPSRC. RLP acknowledges financial support from the Department of Health via the National Institute for Health Research (NIHR) comprehensive Biomedical Research Centre award to Guy's \& St Thomas' NHS Foundation Trust in partnership with King's College London and King's College Hospital NHS Foundation Trust. This work was conducted within the King's College London-UCL Comprehensive Cancer Imaging Centre supported by Cancer Research UK \& EPSRC, in association with MRC and DoH (UK). We thank Dr. M Upton for helpful advice on HPLC methods.

Financial support We acknowledge grants from Guy's \& St Thomas' Charity, Cancer Research UK, EPSRC, MRC and Department of Health and the Wellcome Trust.

Open Access This article is distributed under the terms of the Creative Commons Attribution Noncommercial License which permits any noncommercial use, distribution, and reproduction in any medium, provided the original author(s) and source are credited.

\section{References}

1. Shen DHY, Kloos RT, Mazzaferri EL, Jhiang SM. Sodium iodide symporter in health and disease. Thyroid 2001;11:415-25.

2. Eskandari S, Loo DDF, Dai G, Levy O, Wright EM, Carrasco N. Thyroid Na+/I- symporter. Mechanism, stoichiometry, and specificity. J Biol Chem 1997;272:27230-8.

3. Chung JK. Sodium iodide symporter: its role in nuclear medicine. J Nucl Med 2002;43:1188-200.

4. Dohán O, De la Vieja A, Paroder V, Riedel C, Artani M, Reed M, et al. The sodium/iodide symporter (NIS): characterization, regulation, and medical significance. Endocr Rev 2003;24:48-77. 
5. Eschmann SM, Reischl G, Bilger K, Kupferschläger J, Thelen MH, Dohmen BM, et al. Evaluation of dosimetry of radioiodine therapy in benign and malignant thyroid disorders by means of iodine-124 and PET. Eur J Nucl Med Mol Imaging 2002;29:760-7.

6. Sgouros G, Kolbert KS, Sheikh A, Pentlow KS, Mun EF, Barth A, et al. Patient-specific dosimetry for 131I thyroid cancer therapy using 124I PET and 3-dimensional-internal dosimetry (3D-ID) software. J Nucl Med 2004;45:1366-72.

7. Shin JH, Chung JK, Kang JH, Lee YJ, Kim KI, Kim CW, et al. Feasibility of sodium/iodide symporter gene as a new imaging reporter gene: comparison with HSV1-tk. Eur J Nucl Med Mol Imaging 2004;31:425-32.

8. Groot-Wassink T, Aboagye EO, Glaser M, Lemoine NR, Vassaux G. Adenovirus biodistribution and noninvasive imaging of gene expression in vivo by positron emission tomography using human sodium/iodide symporter as reporter gene. Hum Gene Ther 2002;13:1723-35.

9. Lewis MR. A "new" reporter in the field of imaging reporter genes: correlating gene expression and function of the sodium/ iodide symporter. J Nucl Med 2006;47:1-3.

10. Bruno R, Giannasio P, Ronga G, Baudin E, Travagli JP, Russo D, et al. Sodium iodide symporter expression and radioiodine distribution in extrathyroidal tissues. J Endocrinol Invest 2004;27:1010-4.

11. Miyagawa M, Anton M, Wagner B, Haubner R, Souvatzoglou M, Gansbacher B, et al. Non-invasive imaging of cardiac transgene expression with PET: comparison of the human sodium/iodide symporter gene and HSV1-tk as the reporter gene. Eur J Nucl Med Mol Imaging 2005;32:1108-14.

12. Groot-Wassink T, Aboagye EO, Wang YH, Lemoine NR, Reader AJ, Vassaux G. Quantitative imaging of $\mathrm{Na} / \mathrm{I}$ symporter transgene expression using positron emission tomography in the living animal. Mol Ther 2004;9:436-42.

13. Freudenberg LS, Antoch G, Jentzen W, Pink R, Knust J, Görges $\mathrm{R}$, et al. Value of (124)I-PET/CT in staging of patients with differentiated thyroid cancer. Eur Radiol 2004;14:2092-8.

14. Frey P, Townsend D, Flattet A, De Gautard R, Widgren S, Jeavons A, et al. Tomographic imaging of the human thyroid using 124I. J Clin Endocrinol Metab 1986;63:918-27.

15. Freudenberg LS, Jentzen W, Müller SP, Bockisch A. Disseminated iodine-avid lung metastases in differentiated thyroid cancer: a challenge to 124I PET. Eur J Nucl Med Mol Imaging 2008;35:502-8.

16. Hobbs RF, Wahl RL, Lodge MA, Javadi MS, Cho SY, Chien DT, et al. 124I PET-based 3D-RD dosimetry for a pediatric thyroid cancer patient: real-time treatment planning and methodologic comparison. J Nucl Med 2009;50(11):1844-7.

17. Szajek LP, Der M, Divel J, Huang BX, Plascjak P, Eckelman WC. Production and radioassay of Tc-94m for PET studies. Radiochim Acta 2003;91:613-6.

18. Anbar M, Guttmann S, Lewitus Z. The accumulation of fluoroborate ions in thyroid glands of rats. Endocrinology 1960;66:888-90.

19. Anbar M, Guttmann S, Lewitus Z. Effect of monofluorosulphonate, difluorophosphate and fluoroborate ions on the iodine uptake of the thyroid gland. Nature 1959;183:1517-8.

20. Van Sande J, Massart C, Beauwens R, Schoutens A, Costagliola $\mathrm{S}$, Dumont JE, et al. Anion selectivity by the sodium iodide symporter. Endocrinology 2003;144:247-52.

21. Jones PA, Pendlington RU, Earl LK, Sharma RK, Barratt MD. In vitro investigations of the direct effects of complex anions on thyroidal iodide uptake: identification of novel inhibitors. Toxicol In Vitro 1996;10:149-60.

22. Dadachova E, Nguyen A, Lin EY, Gnatovskiy L, Lu P, Pollard JW. Treatment with rhenium-188-perrhenate and iodine-131 of
NIS-expressing mammary cancer in a mouse model remarkably inhibited tumor growth. Nucl Med Biol 2005;32:695-700.

23. Zuckier LS, Dohan O, Li Y, Chang CJ, Carrasco N, Dadachova E. Kinetics of perrhenate uptake and comparative biodistribution of perrhenate, pertechnetate, and iodide by $\mathrm{NaI}$ symporter-expressing tissues in vivo. J Nucl Med 2004;45:500-7.

24. Carlin S, Mairs RJ, Welsh P, Zalutsky MR. Sodium-iodide symporter (NIS)-mediated accumulation of [(211)At]astatide in NIS-transfected human cancer cells. Nucl Med Biol 2002;29:729 39.

25. Petrich T, Helmeke HJ, Meyer GJ, Knapp WH, Pötter E. Establishment of radioactive astatine and iodine uptake in cancer cell lines expressing the human sodium/iodide symporter. Eur J Nucl Med Mol Imaging 2002;29:842-54.

26. Petrich T, Quintanilla-Martinez L, Korkmaz Z, Samson E, Helmeke HJ, Meyer GJ, et al. Effective cancer therapy with the alpha-particle emitter [211At]astatine in a mouse model of genetically modified sodium/iodide symporter-expressing tumors. Clin Cancer Res 2006;12:1342-8.

27. Willhauck MJ, Sharif Samani B-R, Gildehaus FJ, Wolf I, Senekowitsch-Schmidtke R, Stark HJ, et al. Application of 188rhenium as an alternative radionuclide for treatment of prostate cancer after tumor-specific sodium iodide symporter gene expression. J Clin Endocrinol Metab 2007;92:4451-8.

28. Anbar M, Guttmann S. The isotopic exchange of fluoroboric acid with hydrofluoric acid. J Phys Chem 1960;64:1896-9.

29. Lecat-Guillet N, Ambroise Y. Discovery of aryltrifluoroborates as potent sodium/iodide symporter (NIS) inhibitors. ChemMedChem 2008;3:1207-9.

30. Rugh R. The mouse thyroid and radioactive iodine (I-131). J Morphol 1951;89:323-65.

31. Suzuki H, Willingham MC, Cheng S-Y. Mice with a mutation in the thyroid hormone receptor beta gene spontaneously develop thyroid carcinoma: a mouse model of thyroid carcinogenesis. Thyroid 2002;12:963-9.

32. Lewitus Z, Guttmann S, Anbar M. Effect of thyroid-stimulating hormone (TSH) on the accumulation of perchlorate and fluoroborate ions in thyroid glands of rats. Endocrinology 1962;70:295-7.

33. Saito K, Yamamoto K, Takai T, Yoshida S. Inhibition of iodide accumulation by perchlorate and thiocyanate in a model of the thyroid iodide transport system. Acta Endocrinol 1983;104:45661.

34. Kallee E, Wahl R, Scherbaum W, Anger K. Selective blocking of thyroid adenomas using small doses of perchlorate. Med Welt 1978:29:1641-4. German.

35. Blower PJ. Extending the life of a 99Tcm generator: a simple and convenient method for concentrating generator eluate for clinical use. Nucl Med Commun 1993;14:995-7.

36. Chen LB, Altman A, Mier W, Lu HK, Zhu RS, Haberkorn U. $99 \mathrm{mTc}$-pertechnetate uptake in hepatoma cells due to tissuespecific human sodium iodide symporter gene expression. Nucl Med Biol 2006;33:575-80.

37. Riedel C, Levy O, Carrasco N. Post-transcriptional regulation of the sodium/iodide symporter by thyrotropin. J Biol Chem 2001;276:21458-63.

38. Jeker LT, Hejazi M, Burek CL, Rose NR, Caturegli P. Mouse thyroid primary culture. Biochem Biophys Res Commun 1999;257:511-5.

39. Steffen A-C, Almqvist Y, Chyan M-K, Lundqvist H, Tolmachev V, Wilbur DS, et al. Biodistribution of 211At labeled HER-2 binding affibody molecules in mice. Oncol Rep 2007;17:1141-7.

40. Dohán O, Carrasco N. Advances in $\mathrm{Na}(+) / \mathrm{I}(-)$ symporter (NIS) research in the thyroid and beyond. Mol Cell Endocrinol 2003;213:59-70. 